\title{
Including an ocean carbon cycle model into $i$ LOVECLIM (v1.0)
}

\author{
N. Bouttes ${ }^{1}$, D. M. Roche ${ }^{2,3}$, V. Mariotti ${ }^{2}$, and L. Bopp ${ }^{2}$ \\ ${ }^{1}$ NCAS-Climate, University of Reading, Reading, UK \\ ${ }^{2}$ Laboratoire des Sciences du Climat et de l'Environnement (LSCE), CEA/CNRS-INSU/UVSQ, Gif-sur-Yvette Cedex, France \\ ${ }^{3}$ Earth and Climate Cluster, Faculty of Earth and Life Sciences, Vrije Universiteit Amsterdam, Amsterdam, the Netherlands
}

Correspondence to: N. Bouttes (n.bouttes@reading.ac.uk)

Received: 8 April 2014 - Published in Geosci. Model Dev. Discuss.: 12 June 2014

Revised: 16 April 2015 - Accepted: 25 April 2015 - Published: 28 May 2015

\begin{abstract}
The atmospheric carbon dioxide concentration plays a crucial role in the radiative balance and as such has a strong influence on the evolution of climate. Because of the numerous interactions between climate and the carbon cycle, it is necessary to include a model of the carbon cycle within a climate model to understand and simulate past and future changes of the carbon cycle. In particular, natural variations of atmospheric $\mathrm{CO}_{2}$ have happened in the past, while anthropogenic carbon emissions are likely to continue in the future. To study changes of the carbon cycle and climate on timescales of a few hundred to a few thousand years, we have included a simple carbon cycle model into the $i$ LOVECLIM Earth System Model. In this study, we describe the ocean and terrestrial biosphere carbon cycle models and their performance relative to observational data. We focus on the main carbon cycle variables including the carbon isotope ratios $\delta^{13} \mathrm{C}$ and the $\Delta^{14} \mathrm{C}$. We show that the model results are in good agreement with modern observations both at the surface and in the deep ocean for the main variables, in particular phosphates, dissolved inorganic carbon and the carbon isotopes.
\end{abstract}

\section{Introduction}

The carbon cycle is a key component of climate and environmental sciences, both because $\mathrm{CO}_{2}$ is a greenhouse gas (Tyndall, 1861) and has a direct impact on climate, but also because it plays an important role in ocean acidification (Orr et al., 2005) which directly impacts marine life. The three main carbon reservoirs involved on the timescale of a few thousand years are the atmosphere, the ocean and the land biosphere. The ocean is the biggest of the three reser- voirs with around $39000 \mathrm{GtC}$, while the atmosphere contains around $589 \mathrm{GtC}$ and the terrestrial biosphere between 1950 and $3050 \mathrm{GtC}$ for the pre-industrial (Ciais et al., 2013). The climate also impacts the carbon cycle and hence the concentration of atmospheric $\mathrm{CO}_{2}$ through various dynamical, chemical and biological processes. For example, changes in the ocean temperature will modify the solubility of $\mathrm{CO}_{2}$ : the warmer the ocean the less soluble $\mathrm{CO}_{2}$ becomes, which decreases the carbon stock in the ocean and increases atmospheric $\mathrm{CO}_{2}$. Temperature, as well as humidity, also influences the development of the terrestrial biosphere and decomposition of terrestrial organic matter. Low temperature and dry conditions tend to favour lower rates of decomposition. The various climate-carbon interactions involve all three carbon reservoirs. Therefore it is necessary to include a model of the carbon cycle within a climate model to understand past changes and anticipate the future evolution of the carbon cycle and climate.

Such models have been developed during the last decades (Cox et al., 2000; Friedlingstein et al., 2001) and a subset of coupled models used in CMIP5 (Coupled Model Intercomparison Project 5) now include a complete description of the ocean and land carbon cycles. Eleven models have been compared within the framework of the Fourth Coupled Carbon Cycle Climate Model Intercomparison Project (C4MIP) (Friedlingstein et al., 2006). They include models of both the ocean and the land carbon cycle.

Climate models range from simple box models to global climate models (GCMs). The carbon models have gradually become more complex by including more types of plankton in the ocean and more plant functional types on land, as well as more nutrients, such as iron in the ocean or nitrogen on land (Anav et al., 2013). The number of addi- 
tional tracers directly impacts the computing time, therefore such complex models are well suited to study the climatecarbon evolution on timescales of a few decades to hundreds of years, but are too computationally expensive for longer simulations. Simpler carbon models such as the ocean carbon models based on NPZD (nutrient-phytoplanktonzooplankton-detritus) ecosystems, and simple terrestrial biosphere models with a few plant functional types, associated with intermediate-complexity climate models, are thus more convenient for the study of long timescales of more than a few thousand years.

Intermediate-complexity models are well suited for long term studies of a few thousand to hundred of thousand years, and in particular the glacial-interglacial cycles. The carbon cycle varies greatly during the glacial and interglacial periods, with atmospheric $\mathrm{CO}_{2}$ concentrations of around $190 \mathrm{ppm}$ during the relatively colder glacials periods and around $280 \mathrm{ppm}$ during the warmer interglacials (EPICA community members, 2004). Although such periods have already been studied with intermediate-complexity models (Brovkin et al., 2007; d'Orgeville et al., 2010; Bouttes et al., 2010; Tschumi et al., 2011; Menviel et al., 2012), large uncertainties remain concerning the processes responsible for the changes of the carbon cycle.

Besides understanding and simulating $\mathrm{CO}_{2}$ concentrations in the past and future, the carbon cycle also provides indirect yet valuable information about changes of the ocean dynamics and biology, as well as the land vegetation, through carbon isotopes changes (Duplessy et al., 1988; Crowley, 1995). Indeed, there are no direct data of ocean circulation changes in the past (except for the last decades, see for example Mielke et al., 2013), but the measurement of $\delta^{13} \mathrm{C}$ and $\Delta^{14} \mathrm{C}$ in sediment cores can help constrain the ocean and land vegetation changes. Moreover, the measure of atmospheric $\delta^{13} \mathrm{C}$ in ice cores (Lourantou et al., 2010; Schmitt et al., 2012) and the calibration curves of atmospheric $\Delta^{14} \mathrm{C}$ (Reimer et al., 2013, 2009) provide additional data and constraints. By explicitly simulating the carbon isotopes within the carbon cycle model, as we have done in the iLOVECLIM model, it is possible to directly compare model results with data to calibrate model simulations and improve our understanding.

Our long-term objective is to study past and future carbon cycle changes over timescales of a few thousand to hundred of thousand years, typical of glacial-interglacial changes. The $i$ LOVECLIM model is perfectly suited to such studies since it includes the relevant physical and dynamical components of the ocean, atmosphere and terrestrial biosphere while running fast enough to simulate thousands of years in a reasonable amount of time (500 simulated years per day). To avoid increasing the computing time excessively, the ocean carbon cycle that we included in $i$ LOVECLIM is based on a NPZD ecosystem which provides the main mechanisms relevant on the timescales of hundreds to thousands years, and includes the carbon isotopes. Sedimentary processes would also be relevant to such timescales. However, the introduction of a sediment model is beyond the scope of this study and remains to be done in future work. The terrestrial biosphere already included in $i$ LOVECLIM has been further developed to add the carbon pools and carbon isotopes. Here, we evaluate the results obtained by including the model of ocean carbon in iLOVECLIM. We focus on the main variables from the carbon cycle and on the ocean carbon isotopes $\left(\delta^{13} \mathrm{C}\right.$ and $\left.\Delta^{14} \mathrm{C}\right)$.

\section{Model description and experiment}

\section{1 iLOVECLIM}

The $i$ LOVECLIM model is a new development branch (code fork) of the LOVECLIM model in its version 1.2, as presented in Goosse et al. (2010). It is identical to the latter with respect to its base components: atmosphere, ocean and vegetation (AOV). It has been modified in a number of aspects to include water oxygen isotopes (Roche, 2013) and an interactive ice sheet model (Roche et al., 2014). The general goal of the new developments within iLOVECLIM is to include the suite of processes needed for climate simulations on the Milankovic timescale. We summarize in the following the main characteristics of the AOV components as described in Roche et al. (2007) and Goosse et al. (2010). The following paragraph is taken from Roche et al. (2014).

The atmospheric component ECBilt was developed at the Dutch Royal Meteorological Institute (KNMI) (Opsteegh et al., 1998). Its dynamical core is based on quasi-geostrophic approximation with additional ageostrophic terms added to improve the representation of the Hadley cell dynamics. It is run on a spectral grid with a T21 truncation $\left(\simeq 5.6^{\circ}\right.$ in latitude/longitude in the physical space). ECBilt has three vertical layers at 800,500 and $200 \mathrm{hPa}$. Only the first layer contains humidity as a prognostic variable. The time step of integration of ECBilt is $4 \mathrm{~h}$. The oceanic component (CLIO) is a 3-D oceanic general circulation model (Goosse and Fichefet, 1999) based on the Navier-Stokes equations. It is discretized on an Arakawa B-grid at approximately $3^{\circ} \times 3^{\circ}$ resolution. The vertical discretization follows a " $z$ coordinate" on $20 \mathrm{lev}$ els. It has a free surface that allows the use of real freshwater fluxes, a parametrization of downslope currents (Campin and Goosse, 1999) and a realistic bathymetry. CLIO includes a dynamicalthermodynamical sea-ice component that is an updated version of Fichefet and Morales Maqueda (1997, 1999). The dynamic land vegetation model (VECODE) was specifically designed for longterm computation and coupling to coarse resolution models (Brovkin et al., 1997). VECODE con- 


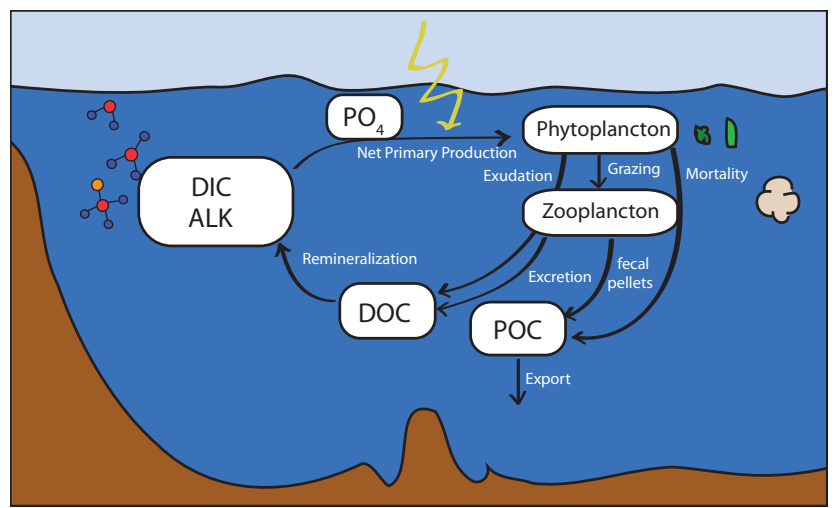

Figure 1. Schematic of the ocean carbon cycle in iLOVECLIM.

sists of three sub-models: (1) a model of vegetation structure (bioclimatic classification) calculates plant functional type (PFT) fractions in equilibrium with climate; (2) a biogeochemical model computes net primary productivity (NPP), allocation of NPP, and carbon pool dynamics (leaves, trunks, litter and soil carbon pools); (3) a vegetation dynamics model. The latter computes two plant functional types (PFTs: trees and grass) and a dummy type (bare soil). The vegetation model is resolved on the atmospheric grid (hence at T21 resolution) and allows fractional allocation of PFTs in the same grid cell to account for the small spatial scale needed by vegetation. The different modules exchange heat, stress and water.

For the sake of clarity, it shall be reminded that the carbon cycle model described here does not have any relationship with the LOCH model as described in Goosse et al. (2010).

\subsection{Carbon cycle model}

\subsubsection{Carbon cycle in the ocean}

The ocean carbon cycle model is originally based on the NPZD ecosystem model described in Six and Maier-Reimer (1996) (Fig. 1). It is the same model as the one included in the CLIMBER-2 model of intermediate complexity (Brovkin et al., 2002a, b, 2007) using the same parameter values, except for the remineralization profile and the atmospheric ${ }^{14} \mathrm{C}$, which are described below.

The carbon cycle is divided into inorganic and organic parts. The inorganic carbon is simulated as dissolved inorganic carbon (DIC) and alkalinity (ALK). Both tracers are advected and mixed in the ocean by the advectiondiffusion scheme of iLOVECLIM. As in Brovkin et al. (2002a), the flux of carbon at the air-sea surface is computed from the difference between the partial pressure of $\mathrm{CO}_{2}$ in the atmosphere and ocean (with a gas exchange coefficient of $\left.0.06 \mathrm{~mol} \mathrm{~m}^{-2} \mathrm{yr}^{-1}\right)$. The sea surface $p \mathrm{CO}_{2}$ is computed

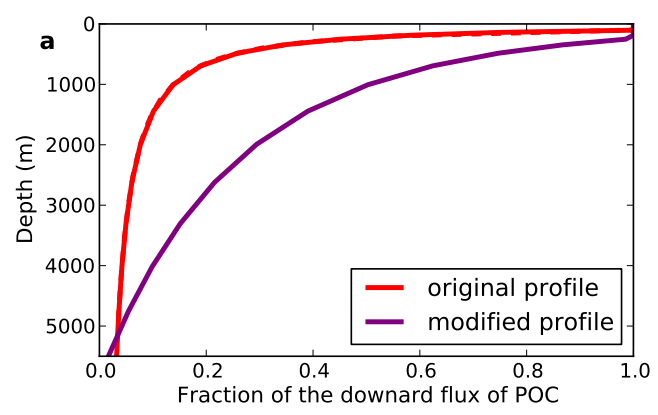

Figure 2. Fraction of particulate organic carbon (POC) which is transported downward at each level (the fraction not transported is remineralized).

from temperature, salinity, DIC and ALK following Millero (1995). The $\mathrm{O}_{2}$ concentration is prescribed to saturation in the surface cell of the ocean.

The organic carbon pool includes six additional tracers on top of inorganic carbon pool, $\mathrm{O}_{2}$ and the nutrients (phosphate and nitrate, which is diagnostically deduced from phosphate by the Redfield ratio): phytoplankton, zooplankton, dissolved organic carbon (DOC), slow dissolved organic carbon (DOCs), particulate organic carbon (POC) and calcium carbonate $\left(\mathrm{CaCO}_{3}\right)$. The phytoplankton synthesizes carbon using the light and nutrients available in the first $100 \mathrm{~m}$ of the ocean (euphotic zone). It then either dies and sinks or is grazed by zooplankton. Part of the plankton is remineralized to DIC, while part of it is exuded to DOC (and DOCs) and the rest is allocated to POC. The $\mathrm{CaCO}_{3}$ production is linearly dependent on the organic carbon production with a fixed coefficient. Both POC and $\mathrm{CaCO}_{3}$ are heavy enough to sink and are instantly remineralized and dissolved at depth. All POC and $\mathrm{CaCO}_{3}$ are remineralized and dissolved in the water column and there is no riverine input. The remineralization profile follows an exponential law as in Brovkin et al. (2002a), but this profile has been slightly modified to have less remineralization in the upper levels and more below (Fig. 2). All the tracers (except for the particulate pools $\mathrm{CaCO}_{3}$ and $\mathrm{POC}$ ) are also transported by the advection-diffusion scheme of $i$ LOVECLIM.

\subsubsection{Carbon cycle in the terrestrial biosphere}

The VECODE terrestrial biosphere model (Brovkin et al., 1997) was already included in $i$ LOVECLIM (Goosse et al., 2010). The model simulates two types of plants - trees and grass - as well as desert. The plants are divided into four compartments that exchange carbon: leaves, wood, litter and soil. Photosynthesis depends on the local climate (precipitation and temperature) and on the atmospheric $\mathrm{CO}_{2}\left(\mathrm{CO}_{2}\right.$ fertilization). We have added the isotopes of carbon to this pre-existing version of VECODE in every carbon compartment as was done in CLIMBER-2. 


\subsubsection{Carbon isotopes}

Following the original CLIMBER-2 version of the carbon cycle model (Brovkin et al., 2002a, b, 2007), the carbon isotopes ${ }^{13} \mathrm{C}$ and ${ }^{14} \mathrm{C}$ are simulated in the ocean and terrestrial biosphere. The ${ }^{13} \mathrm{C}$ is modelled as in Brovkin et al. (2007), while the numerical code has been modified for the ${ }^{14} \mathrm{C}$ which is now interactively dependent on cosmogenic production and carbon cycling in the atmosphere instead of having a fixed atmospheric value (Mariotti et al., 2013).

The ${ }^{13} \mathrm{C}$ simulated in the model is then used as the ratio of ${ }^{13} \mathrm{C}$ on ${ }^{12} \mathrm{C}$ to compare to the $\delta^{13} \mathrm{C}$ data from sediment cores. The $\delta^{13} \mathrm{C}$ is defined as follows:

$\delta^{13} \mathrm{C}=\left(\frac{R}{R_{\text {ref }}}-1\right) \cdot 1000$

with $R=\frac{{ }^{13} \mathrm{C}}{{ }^{12} \mathrm{C}}$.

$R_{\text {ref }}$ is the PDB (Pee Dee Belemnite) carbon isotope standard, which corresponds approximately to average limestone (Craig, 1957).

The ${ }^{13} \mathrm{C}$ distribution in the ocean depends on the airsea exchange, the transport by the ocean circulation (by the advection-diffusion scheme), and the marine biology fractionation. In the terrestrial biosphere, it only depends on the exchange with the atmosphere and the biological fractionation. Indeed, both the marine and terrestrial organisms preferentially use the lighter ${ }^{12} \mathrm{C}$ over ${ }^{13} \mathrm{C}$ during photosynthesis, which tends to increase the $\delta^{13} \mathrm{C}$ in the surrounding environment. When the remineralization occurs, the ${ }^{12} \mathrm{C}$-rich carbon is released, which decreases the $\delta^{13} \mathrm{C}$ in the atmosphere or ocean.

The $\Delta^{14} \mathrm{C}$ is defined as follows (Stuiver and Polach, 1977):

$\Delta^{14} \mathrm{C}=\delta^{14} \mathrm{C}-2\left(\delta^{13} \mathrm{C}+25\right)\left(1+\frac{\delta^{14} \mathrm{C}}{1000}\right)$.

In the model, the simulated ${ }^{14} \mathrm{C}$ is not subject to any isotopic fractionation (neither biological nor through air-sea exchanges). This formulation allows comparison directly with observations and reconstruction data from the sediment cores that are expressed in $\Delta^{14} \mathrm{C}$ without performing a fractionation correction. The content of ${ }^{14} \mathrm{C}$ in a reservoir reflects the time since when this reservoir has been in direct contact with the atmosphere. Thus, ocean $\Delta{ }^{14} \mathrm{C}$ gives a good estimate of the age of water masses, which provides useful indications on ocean circulation pathways. This is particularly interesting in palaeoceanography in order to reconstruct past ocean circulation changes. Moreover, the ${ }^{14} \mathrm{C}$ representation in the model can take into account temporal changes in atmospheric $\Delta^{14} \mathrm{C}$, which has been the case for example during the historical bomb period or the last deglaciation characterized by changes in the production rate. This aspect of the ${ }^{14} \mathrm{C}$ representation will thus be particularly useful on future palaeosimulations.

\subsection{Reference simulation}

The model is run under control boundary conditions set to the pre-industrial values for the orbital parameters, ice sheet reconstruction and atmospheric gas concentrations $\left(\mathrm{CO}_{2}=280 \mathrm{ppm}, \mathrm{CH}_{4}=760 \mathrm{ppb}\right.$ and $\left.\mathrm{N}_{2} \mathrm{O}=270 \mathrm{ppb}\right)$. There are indeed two different $\mathrm{CO}_{2}$ variables in the model: the $\mathrm{CO}_{2}$ used for the radiative code and set to $280 \mathrm{ppm}$, and the one computed by the carbon model. The $\mathrm{CO}_{2}$ used for the radiative code is set to $280 \mathrm{ppm}$ for simplicity and to make sure that the climate is correctly simulated by avoiding feedbacks arising from the wrong $\mathrm{CO}_{2}$ computed by the carbon cycle model. For the reference simulation, as the $\mathrm{CO}_{2}$ concentration simulated by the model is close to $280 \mathrm{ppm}$ it is possible to set the radiative $\mathrm{CO}_{2}$ equal to the $\mathrm{CO}_{2}$ computed in the carbon cycle module, but it would be important to keep them separate for other boundary conditions such as the Last Glacial Maximum as long as the computed $\mathrm{CO}_{2}$ concentration is not equal to the data value of the period studied. Hence the two variables are considered separately in this version of the model, but they could be the same value in future studies. The cosmogenic production of ${ }^{14} \mathrm{C}$ is set to 2.19 atom ${ }^{14} \mathrm{C} \mathrm{cm}^{-2} \mathrm{~s}^{-1}$, which is in the pre-industrial data error bar (Masarik and Beer, 2009). This production flux is then integrated over the Earth surface and added to the ${ }^{14} \mathrm{C}$ concentration of the atmosphere box. The simulation starts from an equilibrium run for the climate, and uniform distribution of tracers in the ocean. The total amount of carbon has been adjusted in iterative runs to reach a value close to the pre-industrial $\mathrm{CO}_{2}$ level of $280 \mathrm{ppm}$ in the atmosphere. The simulation was run until it reached an equilibrium for deep ocean variables ( $\simeq 10000$ years), and the mean of the last 100 years is used to compare the results with existing data.

\subsection{Data}

We compare the model results with existing observations and CMIP5 model simulations. We use temperature, salinity, phosphate and oxygen data from the World Ocean Atlas 2009 (Locarnini et al., 2010; Antonov et al., 2010; Garcia et al., 2010a, b). For the DIC, alkalinity and $\Delta^{14} \mathrm{C}$ we compare results with data from GLODAP (Key et al., 2004). The $p \mathrm{CO}_{2}$ data come from Takahashi et al. (2009) and the $\delta^{13} \mathrm{C}$ data from Schmittner et al. (2013).

The global climate models considered from the Coupled Model Intercomparison Phase 5 (CMIP5) are CESM1-BGC, CMCC-CESM, GFDL-ESM2G, GFDLESM2M,HadGEM2-ES, IPSL-CM5A-LR, IPSL-CM5AMR, MPI-ESM-LR, MPI-ESM-MR and NorESM1-ME. For each variable, the models for which the data were available are listed in Table 1. For more detailed information on the models see Bopp et al. (2013). The results are averaged over the period 1890-1899 from the "historical" simulation. The end of the 19th century is chosen because it is more 

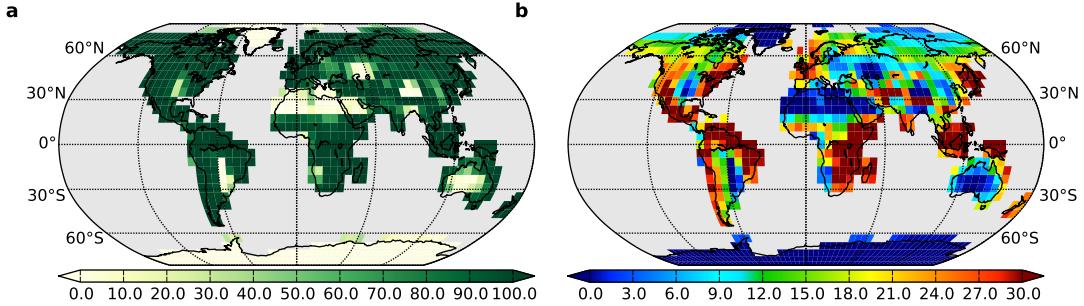

Figure 3. Distribution of (a) total vegetation cover (\%) and (b) total carbon content $\left(\mathrm{kgC} \mathrm{m}^{-2}\right)$.
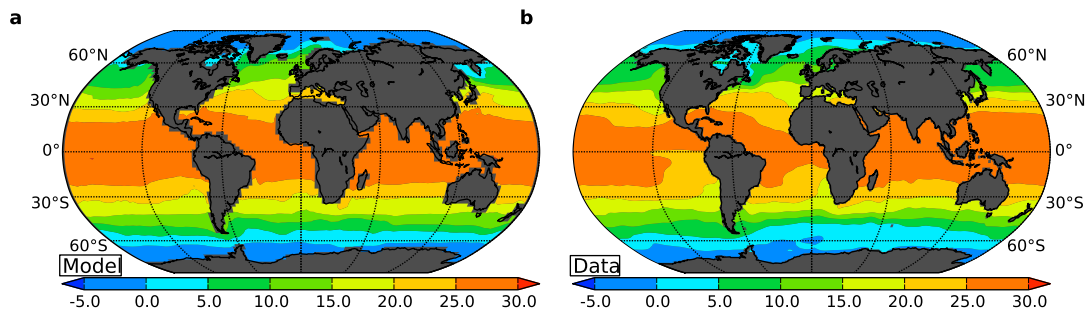

Figure 4. Temperature distribution $\left({ }^{\circ} \mathrm{C}\right)$ at the ocean surface. Data from the World Ocean Atlas 2009 (Locarnini et al., 2010).

Table 1. CMIP5 models considered for each variable (“ $x$ ” for yes, and "-" for no).

\begin{tabular}{lccc}
\hline Model & DIC & ALK & $\mathrm{O}_{2}$ \\
\hline CESM1-BGC & $\times$ & $\times$ & $\times$ \\
CMCC-CESM & $\times$ & $\times$ & $\times$ \\
GFDL-ESM2G & $\times$ & $\times$ & $\times$ \\
GFDL-ESM2M & $\times$ & $\times$ & $\times$ \\
HadGEM2-ES & - & - & $\times$ \\
IPSL-CM5A-LR & $\times$ & $\times$ & $\times$ \\
IPSL-CM5A-MR & $\times$ & $\times$ & $\times$ \\
MPI-ESM-LR & $\times$ & - & - \\
MPI-ESM-MR & - & $\times$ & $\times$ \\
NorESM1-ME & $\times$ & $\times$ & $\times$ \\
\hline
\end{tabular}

similar to the $i$ LOVECLIM simulation. It can be noted that very similar results for the ocean interior are obtained when considering the end of the 20th century instead, due to the long timescale of the deep ocean (a few hundred years).

\section{Results}

After equilibrium, the atmospheric $\mathrm{CO}_{2}$ concentration is $287 \mathrm{ppm}$, the atmospheric $\delta^{13} \mathrm{C}$ value $-6.4 \%$ and the atmospheric $\Delta^{14} \mathrm{C}$ value $1.5 \%$, close to the pre-industrial values of respectively $279 \mathrm{ppm},-6.4 \%$ (Elsig et al., 2009) and $0 \%$ o (Reimer et al., 2009). In the case of $\Delta^{14} \mathrm{C}$, the simulated $-1.5 \%$ is a particularly good estimate of the observed $0 \%$, because uncertainty on pre-industrial $\Delta^{14} \mathrm{C}$ values is of the order of $10 \%$ (Reimer et al., 2009). The ocean contains $39019 \mathrm{GtC}$ and the terrestrial biosphere $2142 \mathrm{GtC}$.
The total vegetation cover simulated by the model (Fig. 3) is in agreement with the one from another version of LOVECLIM (Goose et al., 2010, Fig. 14). Likewise, it is similar to the data but with an overestimation of the cover in the Tropics because of too much precipitation. In terms of carbon content, $i$ LOVECLIM simulates low carbon contents in the regions of low vegetation cover, and particularly high carbon contents in the southern and eastern parts of North America, the northeastern part of South America, the southeastern part of Africa and on the maritime continent. This results in $2142 \mathrm{GtC}$ globally, corresponding to $863 \mathrm{GtC}$ for vegetation and $1279 \mathrm{GtC}$ for soils (and litter). This is in the range of other model estimates which vary between around 320 and $930 \mathrm{GtC}$ for vegetation and between around 500 and $3100 \mathrm{GtC}$ for soils (Anav et al., 2013), as well as close to data estimates although with an overestimation of vegetation carbon content and underestimation of soil carbon content (respectively 450 to $650 \mathrm{GtC}$ for vegetation, Prentice et al., 2013, and 1500 to $2400 \mathrm{GtC}$ for litter and soils, Batjes, 1996).

Because the objective of this coupling is to study the climate and carbon cycle on a timescale of more than thousands of years, and because the terrestrial biosphere has already been studied (apart from the isotopes) (Goosse et al., 2010), we focus mainly on the distribution of the tracers in the ocean, both at the surface and in the interior. We also compare the carbon isotope results with data as they constitute an important constraint for past climates.

\subsection{Ocean dynamics}

The ocean dynamics, which depend on temperature and salinity gradients, play an important role for the carbon cycle because they partly determine the distribution of the tracers 

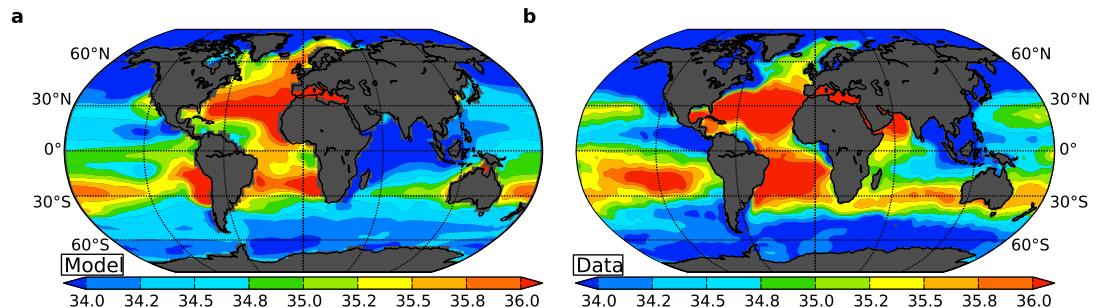

Figure 5. Salinity distribution (psu) at the ocean surface. Data from the World Ocean Atlas 2009 (Antonov et al., 2010).

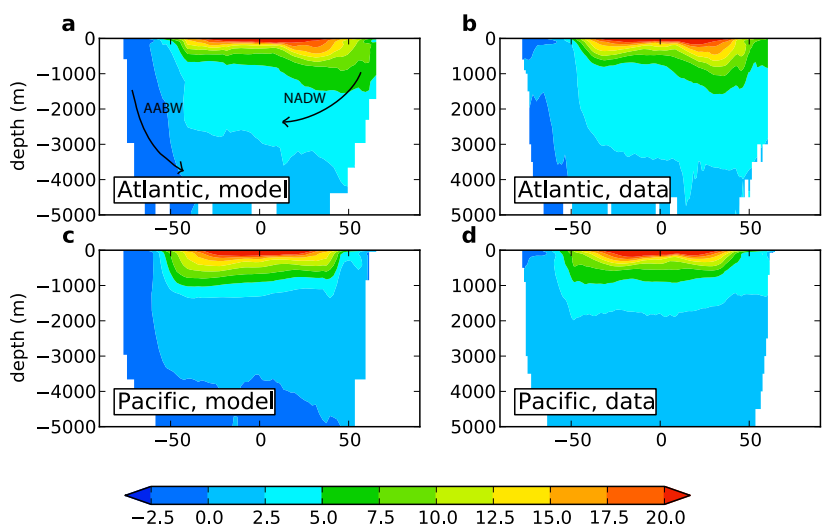

Figure 6. Zonal average of the temperature distribution $\left({ }^{\circ} \mathrm{C}\right)$ in the ocean. Data from the World Ocean Atlas 2009 (Locarnini et al., 2010). North Atlantic Deep Water (NADW) and Antarctic Bottom Water $(\mathrm{AABW})$ are indicated in panel (a).

that are transported. The $i$ LOVECLIM model simulates relatively well the distribution of temperature and salinity both at the surface and in the ocean interior.

At the surface, the simulated temperature field is similar to the observations (Fig. 4), with higher temperatures at the low latitudes and lower at high latitudes. Some local discrepancies can be observed in the boundary currents which are not well represented in the model due to its low resolution. The salinity distribution is in agreement with the data in most places (Fig. 5), except in the two bands of higher salinity in the Pacific and Indian oceans around $30^{\circ} \mathrm{N}$ and $30^{\circ} \mathrm{S}$ and in the northwestern part of the Indian Ocean where the simulated salinity is too low compared to observations.

In the ocean interior, the major oceanic water masses display similar features as in the data (Figs. 6 and 7). The thermocline is well represented in both the Atlantic and Pacific oceans. The Antarctic Bottom Water (AABW), which forms around Antarctica and sinks to the bottom of the ocean, is characterized by very cold temperature and low salinity in the model as in the observations. The North Atlantic Deep Water (NADW) which forms in the North Atlantic high latitudes, has relatively warmer and saltier water, in agreement with data. The low-salinity tongue of the Antarctic Intermediate Water (AAIW), which spreads northward at interme-
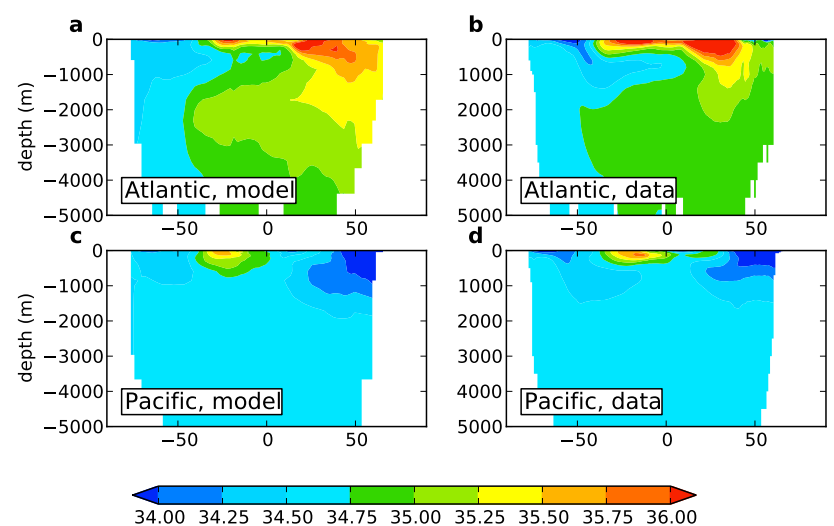

Figure 7. Zonal average of the salinity distribution (psu) in the ocean. Data from the World Ocean Atlas 2009 (Antonov et al., 2010).
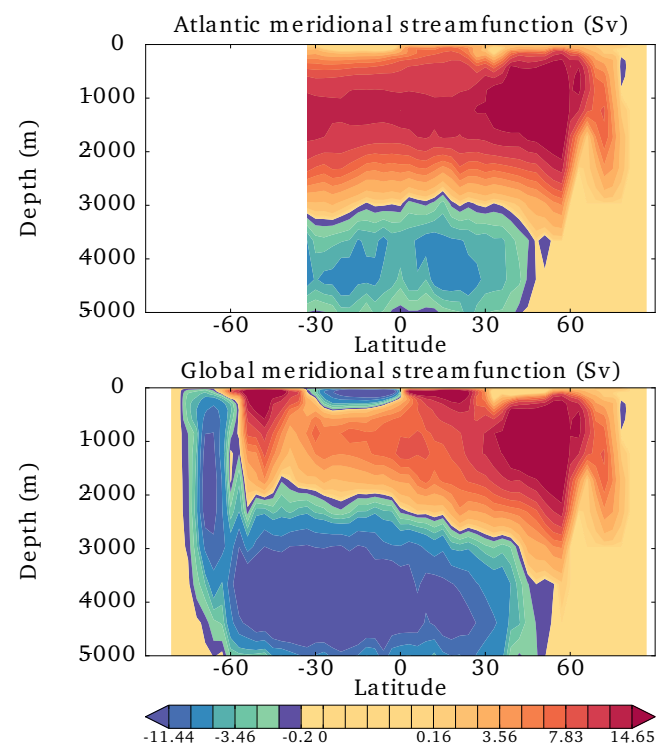

Figure 8. Atlantic and global meridional streamfunction (Sv).

diate depth of around $1000 \mathrm{~m}$ in the Southern Hemisphere, is also well represented in the model. In the Pacific, the penetration of the North Pacific Intermediate Water (NPIW) with low salinity is similar to the observational data. However two main discrepancies can be seen. In the Southern 

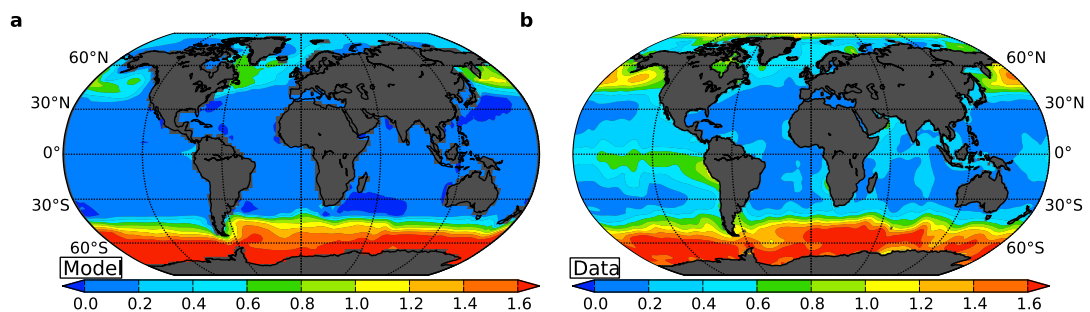

Figure 9. Phosphate distribution at the ocean surface $\left(\mu \mathrm{mol} \mathrm{kg}^{-1}\right)$. Data from the World Ocean Atlas 2009 (Garcia et al., $2010 \mathrm{~b}$ ).

Ocean, AABW is too cold, so that most of the bottom ocean is slightly too cold compared to the data. In the North Atlantic the water that sinks with NADW is too salty because the surface water is also slightly too salty (Fig. 5).

The simulated streamfunction (Fig. 8) is in the range of other models, with a maximum Atlantic Meridional Overturning Circulation (AMOC) value of $21 \mathrm{~Sv}$, compared to values between 14 and $31 \mathrm{~Sv}$ for CMIP5 models (Weaver et al., 2012). Comparing to observation of the AMOC strength (e.g. Srokosz et al., 2012, and references therein), we find an upper limb transport at $26^{\circ} \mathrm{N}$ of about $15 \mathrm{~Sv}$, lower that the 17 to $22 \mathrm{~Sv}$ estimates (Kanzow et al., 2010; Srokosz et al., 2012) from direct measurements. At $16^{\circ} \mathrm{N}$, we obtain a lower limb of about $19 \mathrm{~Sv}$, in good agreement with observations (Send et al., 2011; Srokosz et al., 2012) that infer a transport of $17 \pm 3.5 \mathrm{~Sv}$.

\subsection{Nutrients and oxygen}

The distribution of nutrients depends on the transport by the diffusion-advection scheme of the ocean model, their use by marine biota (net productivity) and remineralization at depth. In the euphotic zone in the first $100 \mathrm{~m}$ below the surface, nutrients are consumed by phytoplankton during photosynthesis, while oxygen is produced. There are thus less nutrients at the surface than in the deep ocean, which can be seen in simulated phosphate concentrations, in agreement with data (Figs. 9 and 10). The surface distribution of simulated phosphates tends to lead to an underestimate of the intensity of boundary currents and upwellings as already seen in the surface temperature field; nonetheless, the low-tohigh latitudes gradient observed in data is well represented (Fig. 9). At the surface the oxygen is set to the saturation level (Figs. 11 and 12). The simulated surface distribution of oxygen tends to be underestimated in the Northwest Atlantic and in the Benguela upwelling, as well as in parts of the Southern Ocean (Fig. 11) but this is due to the too warm temperatures in these areas compared to data (Fig. 4), which decreases the solubility of atmospheric oxygen in the surface water. In the North Atlantic, this error then propagates in the interior resulting in too low oxygen values in the deep North Atlantic. In the ocean interior, the remineralization of plankton consumes oxygen and releases nutrients. This explains the minimum of oxygen and maximum of nutrients around

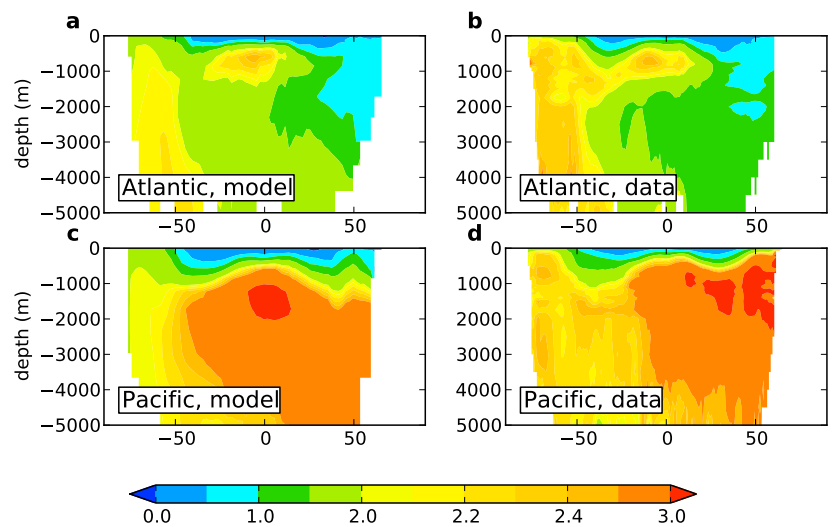

Figure 10. Zonal average of the phosphate distribution in the ocean $\left(\mu \mathrm{mol} \mathrm{kg}{ }^{-1}\right)$. Data from the World Ocean Atlas 2009 (Garcia et al., 2010b).

$500-1000 \mathrm{~m}$ which is relatively well represented in the model compared to data (Figs. 10 and 12).

The differences between the Atlantic and Pacific basins are also well represented. In the North Atlantic, the NADW sinks with lower phosphate values (Fig. 10a and b) and higher $\mathrm{O}_{2}$ values (Fig. 12a and b) from the surface where the waters are enriched in $\mathrm{O}_{2}$ and where nutrients are consumed for photosynthesis. The $\mathrm{O}_{2}$ values in the ocean interior where NADW penetrates are slightly too small in the model because the surface values are too low. In the Pacific, the water is progressively enriched in $\mathrm{PO}_{4}$ (Fig. 10c and d) while it becomes depleted in $\mathrm{O}_{2}$ (Fig. 12c and d) during its transport from the south to the north, because of the constant remineralization which enriches the water in $\mathrm{PO}_{4}$ and uses $\mathrm{O}_{2}$.

\subsection{Carbon}

The simulated distribution of DIC and alkalinity is in relative agreement with the data in the oceans. At the surface, DIC is higher at high latitudes and lower at low latitudes like in the data (Fig. 13), although the DIC levels in the Tropics are slightly too low compared to the data. The alkalinity values are similar to the data, but with some small differences especially in the Atlantic where the data display two zones of higher values in the middle of the tropical gyres which are not very well represented by the model (Fig. 14). This could 

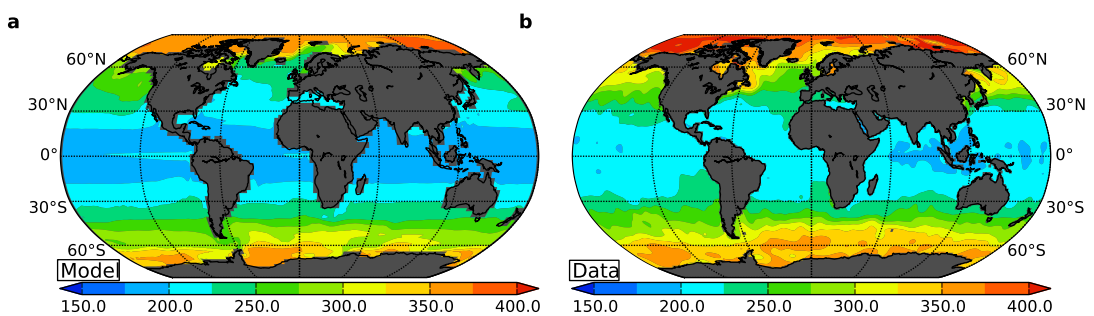

Figure 11. Oxygen distribution at the ocean surface $\left(\mu \mathrm{mol} \mathrm{kg}^{-1}\right)$. Data from the World Ocean Atlas 2009 (Garcia et al., $\left.2010 \mathrm{a}\right)$.

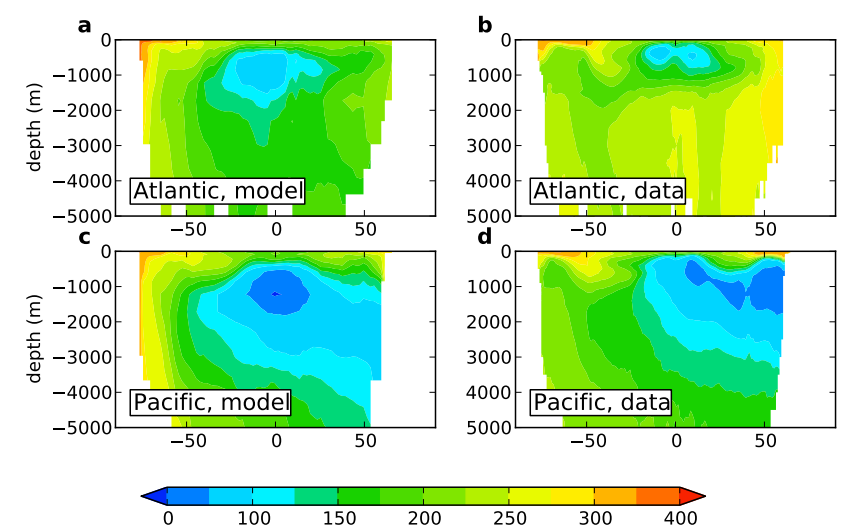

Figure 12. Zonal average of the oxygen distribution in the ocean $(\mu \mathrm{mol} \mathrm{kg}-1$ ). Data from the World Ocean Atlas 2009 (Garcia et al., 2010a).

be due to the dissolution profile of $\mathrm{CaCO}_{3}$ which is a function of depth, as for POC but with different values, and could be improved to be more realistic.

In the ocean interior, NADW is characterized by relatively low DIC values in the model as in the data, although the model values are slightly too high (Fig. 14). In the Pacific, the water becomes progressively enriched in DIC and alkalinity as it goes from the south to the north because of remineralization (Figs. 15 and 16). This is well represented in the model for DIC, however the alkalinity distribution is less well represented in the model, which could be due to the simple linear relation between the production of $\mathrm{CaCO}_{3}$ and the production of organic matter, or the fixed vertical profile of remineralization.

The regions of high and low $p \mathrm{CO}_{2}$ are generally well represented in the model compared to the data (Fig. 17). In particular, the $p \mathrm{CO}_{2}$ values are higher around the equator, where the upwelling brings water with a high carbon content that is lost to the atmosphere, even if the model underestimates these high values. At high latitudes, especially in the North Atlantic and Arctic regions, the $p \mathrm{CO}_{2}$ values are low where the ocean takes up carbon from the atmosphere. However, in the Southern Ocean the data indicate low values, even if they are sparse, which are not shown by the model, but the cause of this mismatch is unknown.

\subsection{Carbon isotopes}

During photosynthesis, the organisms preferentially use the relatively light ${ }^{12} \mathrm{C}$ over ${ }^{13} \mathrm{C}$. This leads to higher $\delta^{13} \mathrm{C}$ values in the surface and lower values deeper in the ocean where remineralization takes place and ${ }^{12} \mathrm{C}$ is released. This is well represented in the model (Fig. 18), as well as the minimum value in the subsurface equatorial Atlantic due to higher remineralization in that region. The $\delta^{13} \mathrm{C}$ also depends on circulation, so that NADW is characterized by relatively high values and AABW by lower values, in agreement with data. In the Pacific, the water is progressively enriched in ${ }^{12} \mathrm{C}$ from remineralization from south to north, resulting in the low $\delta^{13} \mathrm{C}$ values. However, the high $\delta^{13} \mathrm{C}$ values in the North Atlantic do not penetrate far enough south, which could be due to too much diffusion.

As opposed to simulated $\delta^{13} \mathrm{C}$, simulated $\Delta^{14} \mathrm{C}$ does not depend on biology effects, so it allows us to separate the biological and circulation effects registered by $\delta^{13} \mathrm{C}$. The general structure of oceanic $\Delta^{14} \mathrm{C}$ is well simulated by the model (Fig. 19) and reflects the penetration of water masses in the interior of the ocean: from north to south in the Atlantic Ocean and from south to north in the Pacific Ocean. The model performs well compared to other ocean GCMs (Mariotti et al., 2013; Tschumi et al., 2011; Franke et al., 2008; Matsumoto et al., 2004), especially in the intermediate to deep Pacific Ocean. The model values seem nonetheless to decrease too rapidly following the penetration of NADW in the North Atlantic, similarly to $\mathrm{PO}_{4}$, which could indicate that the diffusion is too strong in that region. In the Pacific, the water becomes too depleted in $\Delta^{14} \mathrm{C}$ in the northern part, possibly due to an underestimate of the mixing in that region.

\section{Discussion}

Because the main feature added to $i$ LOVECLIM for the carbon cycle concerns the ocean, we only discuss the results for the oceanic variables. The terrestrial biosphere has only been slightly modified to include the carbon reservoirs, but could benefit from further improvements such as more plant functional types, as well as additional modules such as permafrost, which is work in progress (Kitover et al., 2013). 

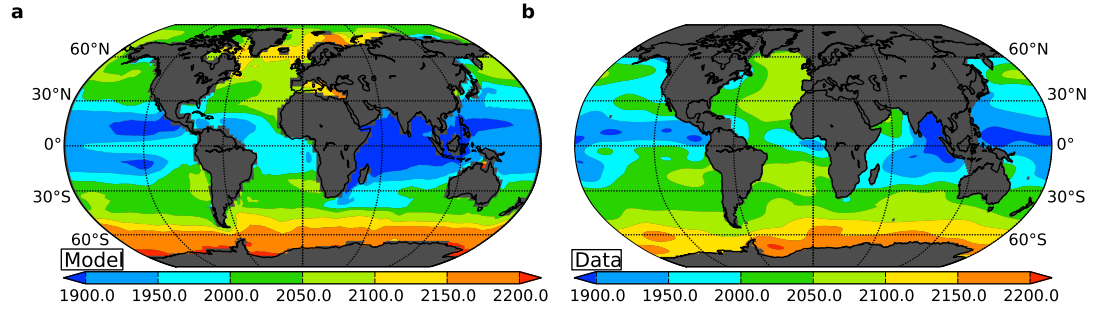

Figure 13. Dissolved inorganic carbon (DIC) distribution at the ocean surface $\left(\mu \mathrm{mol} \mathrm{kg}{ }^{-1}\right)$. Data from GLODAP (Key et al., 2004).
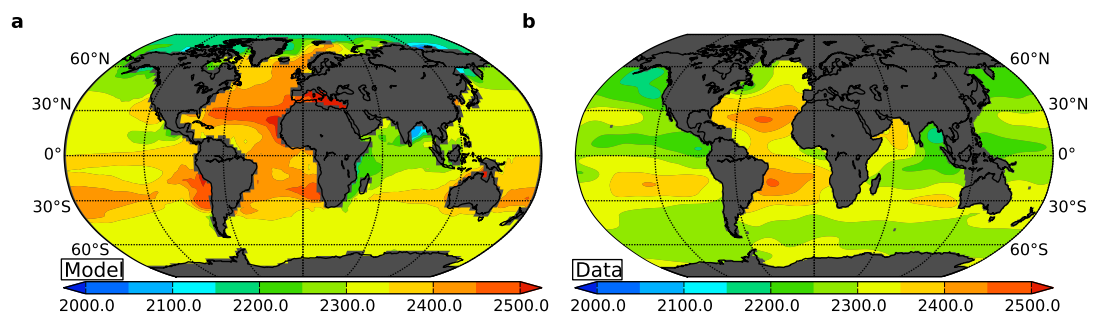

Figure 14. Alkalinity (ALK) distribution at the ocean surface $\left(\mu \mathrm{mol} \mathrm{kg}^{-1}\right)$. Data from GLODAP (Key et al., 2004).

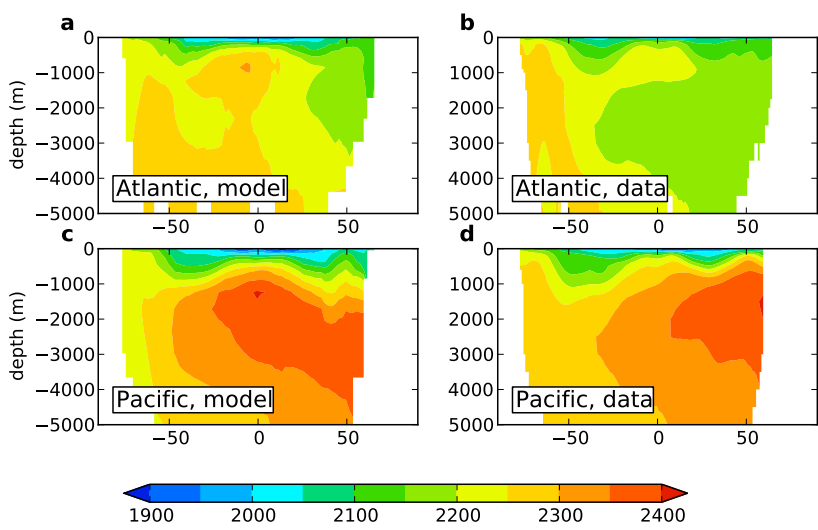

Figure 15. Zonal average of the dissolved inorganic carbon (DIC) distribution in the ocean $\left(\mu \mathrm{mol} \mathrm{kg}{ }^{-1}\right)$. Data from GLODAP (Key et al., 2004).

\subsection{Model-data comparison}

The $i$ LOVECLIM model simulates most of the variables in agreement with data, especially the main characteristics of the water masses. However, a number of discrepancies exist. Some are due to errors in the simulation of surface regional features which then propagate in the ocean interior, such as the North Atlantic where the high salinity from the Tropics is transported too much northward compared to the data. This could be partly due to the resolution of the model which limits the representation of small-scale features. The misrepresentation of temperature has a direct impact on oxygen, for example again in the North Atlantic where the temperatures are too high, which leads to too small values of oxygen in the surface and in the ocean interior. Another source of error

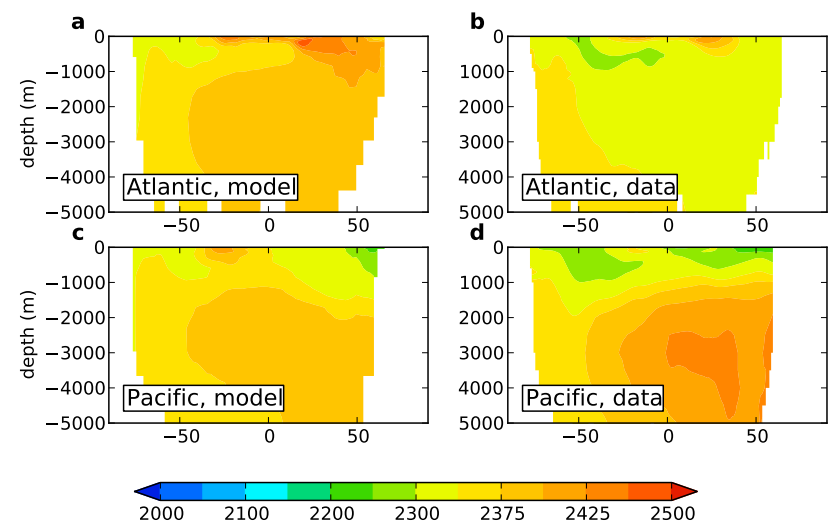

Figure 16. Zonal average of the alkalinity (ALK) distribution in the ocean $\left(\mu \mathrm{mol} \mathrm{kg}{ }^{-1}\right)$. Data from GLODAP (Key et al., 2004).

could come from the diffusion which seems too strong in the North Atlantic where the characteristic values of NADW for salinity, $\mathrm{PO}_{4}$, DIC and carbon isotopes decrease too rapidly while it penetrates southward. This highlights the crucial role of a correct representation of temperature and salinity and the associated ocean circulation in setting the distribution of the biogeochemical variables. The distribution of the variables strongly depends on salinity and temperature distribution: if it is improved it should also improve the carbon cycle.

\subsection{Inter-model comparison}

We compare the $i$ LOVECLIM results with other models using the data from the Coupled Model Intercomparison Phase 5 (CMIP5). We focus on three key variables (dissolved inorganic carbon, alkalinity and oxygen) using the 

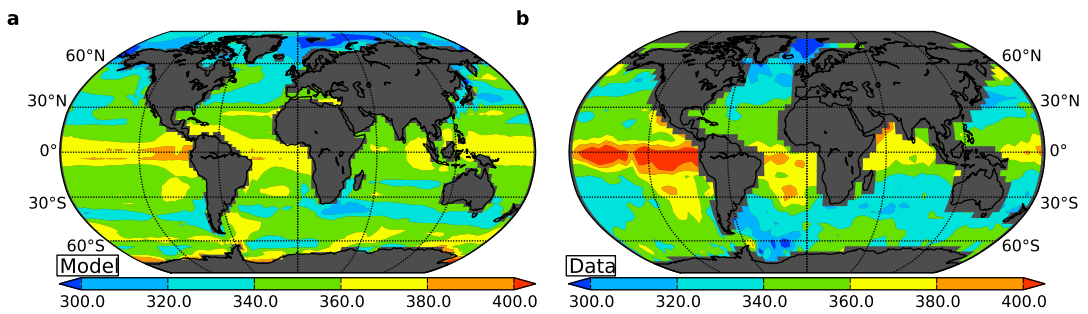

Figure 17. $p \mathrm{CO}_{2}$ distribution at the ocean surface ( $\mu$ atm). Data from Takahashi et al. (2009).

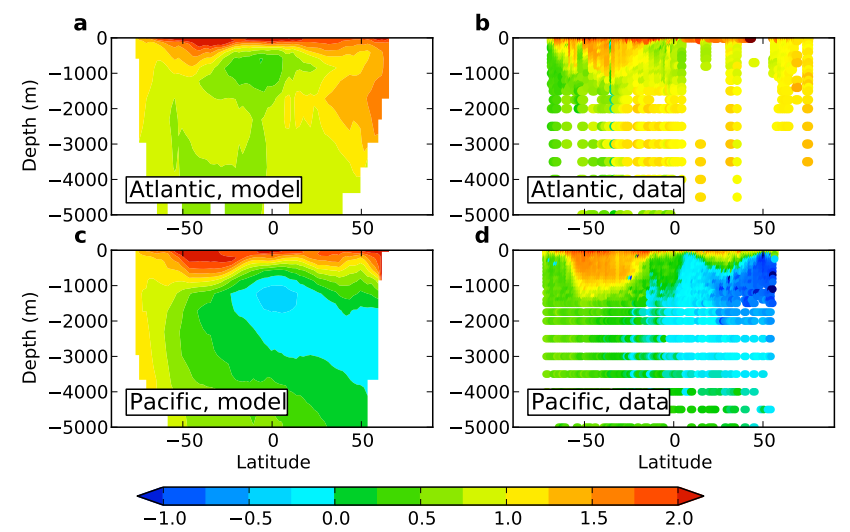

Figure 18. Zonal average of the $\delta^{13} \mathrm{C}$ distribution in the ocean (\%o). Data from Schmittner et al. (2013).

average over years 1890-1899 of the "historical" simulation (see Sect. 2.4). The data are zonally averaged for the Atlantic and Pacific basins (including the Southern Ocean). Note that the simulations that are compared are not exactly the same: the $i$ LOVECLIM simulation is a long simulation of a few thousand years under pre-industrial conditions, whereas the CMIP5 simulations are run under evolving boundary conditions of the historical period since 1850 starting from spin-up simulations of a few hundred to one thousand years. Additionally, the spatial resolution is higher in the CMIP5 models which are fully coupled GCMs. Nevertheless, we show here that the skill scores of $i$ LOVECLIM are similar to those of more complex Earth system models used in CMIP5.

For most variables, iLOVECLIM is in the range of other models performance. For DIC the models that statistically perform best in both the Atlantic and Pacific are the IPSL-CM5A-LR and IPSL-CM5A-MR models (Fig. 20). $i$ LOVECLIM is less accurate than the IPSL models, but still reproduces most of the pattern and gives better results than other models such as NorESM1-ME, CMCC-CESM, GFDL-ESM2G or MPI-ESM-LR in terms of correlation and root mean square error. For alkalinity, most models simulate poorly the distribution especially in the Atlantic basin, where $i$ LOVECLIM is performing particularly poorly (Fig. 21). In the Pacific, which represents a larger volume, the models yields better results and so does $i$ LOVECLIM, which lies in

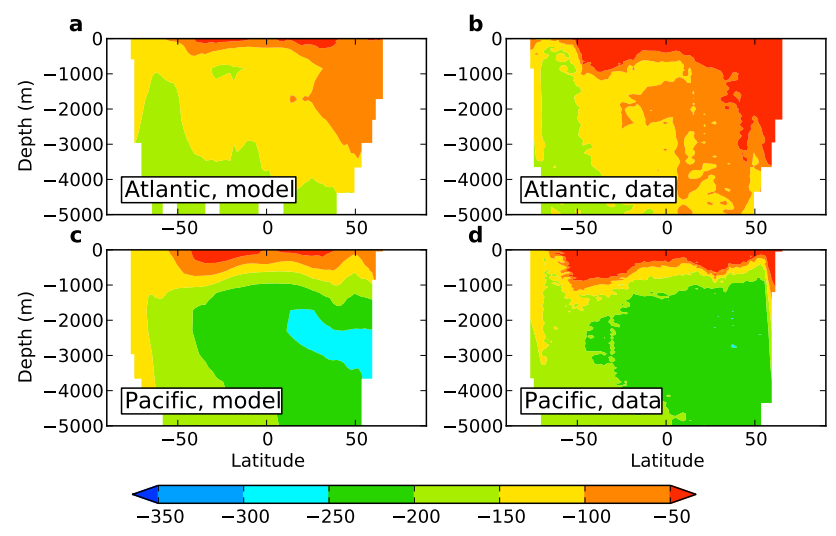

Figure 19. Zonal average of the $\Delta^{14} \mathrm{C}$ distribution in the ocean (\%o). Data from GLODAP (Key et al., 2004).

the middle of the ensemble. This highlights the need of better understanding the processes responsible for the change of alkalinity to improve its distribution in models. For the oxygen, $i$ LOVECLIM lies behind most models in the Atlantic but is in the middle of the range in the Pacific (Fig. 22). In the Atlantic basin, this is partly due to the representation of the high $\mathrm{O}_{2}$ values penetrating in the North Atlantic with NADW that is not well reproduced in $i$ LOVECLIM because the $\mathrm{O}_{2}$ values are too low at the surface. Future work will focus on understanding the causes of the mismatch to improve the $\mathrm{O}_{2}$ distribution. In the Pacific basin $i$ LOVECLIM has a good correlation at around 0.8 like most models. This is not as good as a few models with correlations higher than 0.9 such as CESM1-BGC, MPI-ESM-MR and MPI-ESM-LR, but relatively good and better than NorESM1-ME with a correlation of only 0.5 .

\subsection{Future developments}

Overall, iLOVECLIM does a relatively good job compared to the data and other models and usually lies in the middle of the CMIP5 range. This is a good performance given that $i$ LOVECLIM is an EMIC and has a less complex and comprehensive representation of the different processes than the CMIP5 GCMs. The GCMs usually simulate better the ocean circulation which yields better distribution of the geochemical variables. There are however a few points that need to be 
DIC

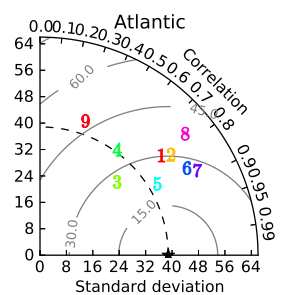

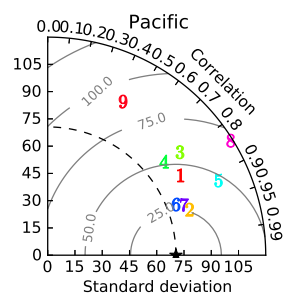

Standard deviation

Figure 20. Comparison of the latitude-depth pattern of zonally averaged dissolved inorganic carbon in the Atlantic and Pacific basins (Taylor diagrams). Data from GLODAP (Key et al., 2004).

ALK
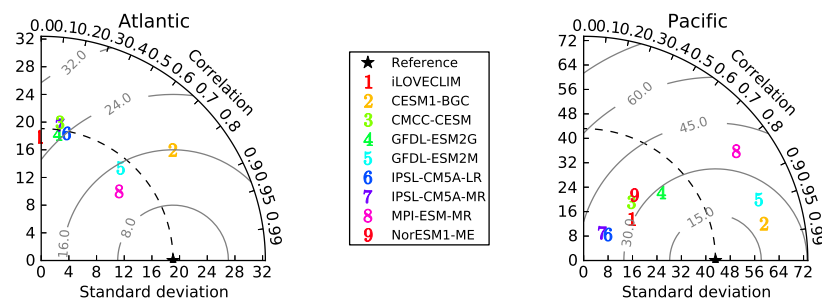

Figure 21. Comparison of the latitude-depth pattern of zonally averaged alkalinity in the Atlantic and Pacific basins (Taylor diagrams). Data from GLODAP (Key et al., 2004).

improved in $i$ LOVECLIM, namely the $\mathrm{O}_{2}$ representation in the Atlantic and the alkalinity distribution (like in all other models).

Some limitations arise from the simplicity of the NPZD model which does not include iron nor silicate. This could be added in future work. The air-sea flux of oxygen has not yet been parametrized depending on the difference between the atmosphere and surface water values and the wind, but this will be explored in future studies. It could improve the regional distribution of oxygen values, and would also modify the temporal evolution of oxygen values in transient simulations. Work has been done in other models showing the importance of remineralization on the carbon cycle (Schneider et al., 2008; Kwon et al., 2009). The profile, which depends on depth, is currently fixed, but the effect of changing the values depending on the temperature or other variables should be evaluated. The production and dissolution of $\mathrm{CaCO}_{3}$ could also be improved, which would yield better results for the alkalinity distribution. In particular, $\mathrm{CaCO}_{3}$ production is currently proportional to the production of organic matter, which could be modified, and the vertical dissolution profile is fixed, which could be changed to take into account the saturation state.
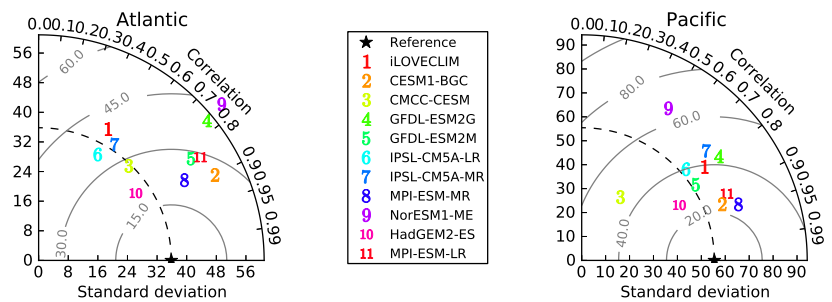

Figure 22. Comparison of the latitude-depth pattern of zonally averaged oxygen in the Atlantic and Pacific basins (Taylor diagrams). Data from the World Ocean Atlas 2009 (Garcia et al., 2010a).

\section{Conclusions}

We have described the implementation of a carbon cycle module in the $i$ LOVECLIM model, including the carbon isotopes ${ }^{13} \mathrm{C}$ and ${ }^{14} \mathrm{C}$. Comparison with modern data show that the model performs well for the main carbon cycle variables, and reproduces the most important features of the different water masses. In particular, the good representation of the ${ }^{13} \mathrm{C}$ and ${ }^{14} \mathrm{C}$ in the ocean interior paves the way for past studies for which they represent most of the available data. Therefore the $i$ LOVECLIM model with the carbon cycle is well suited for long-term simulations of a few thousand years in the past but also in the future. Some improvements will be considered in future work, such as the inclusion of iron and silicate, a better parametrization of the $\mathrm{O}_{2}$ air-sea exchange with wind and better parametrization of the remineralization and dissolution profiles. Finally, a sediment model remains to be coupled to include all relevant oceanic components of the carbon cycle on timescales of a few thousand years.

\section{Code availability}

The $i$ LOVECLIM source code is based on the LOVECLIM model version 1.2 whose code is accessible at http:// www.elic.ucl.ac.be/modx/elic/index.php?id=289. The developments on the $i$ LOVECLIM source code are hosted at https: //forge.ipsl.jussieu.fr/ludus but are not publicly available due to copyright restrictions. Access can be granted on demand by request to D. M. Roche (didier.roche@1sce.ipsl.fr).

Acknowledgements. D. M. Roche is supported by INSU/CNRS and NWO. V. Mariotti-Epelbaum is supported by the French National Center for Scientific Research funding. N. Bouttes is supported by the European Research Council under the European Community's Seventh Framework Programme (FP7/2007-2013), ERC grant agreement number 247220, project Seachange. This is a contribution to the ACCLIMATE ERC project; the research leading to these results has received funding from the European Research Council under the European Union's Seventh Framework 
Programme (FP7/2007-2013)/ERC grant agreement no. 339108. We thank the editor and two reviewers for their comments, which helped improve this paper.

Edited by: C. Sierra

\section{References}

Anav, A., Friedlingstein, P., Kidston, M., Bopp, L., Ciais, P., Cox, P., Jones, C., Jung, M., Myneni, R., and Zhu, Z.: Evaluating the Land and Ocean Components of the Global Carbon Cycle in the CMIP5 Earth System Models, J. Climate, 26, 6801-6843, doi:10.1175/JCLI-D-12-00417.1, 2013.

Antonov, J. I., Seidov, D., Boyer, T. P., Locarnini, R. A., Mishonov, A. V., Garcia, H. E., Baranova, O. K., Zweng, M. M., and Johnson, D. R.: World Ocean Atlas 2009, Volume 2: Salinity, edited by: Levitus, S., NOAA Atlas NESDIS 69, US Government Printing Office, Washington, D.C., 184 pp., 2010.

Batjes, N. H.: Total carbon and nitrogen in the soils of the world, Eur. J. Soil Sci., 47, 151-163, 1996.

Bopp, L., Resplandy, L., Orr, J. C., Doney, S. C., Dunne, J. P., Gehlen, M., Halloran, P., Heinze, C., Ilyina, T., Séférian, R., Tjiputra, J., and Vichi, M.: Multiple stressors of ocean ecosystems in the 21st century: projections with CMIP5 models, Biogeosciences, 10, 6225-6245, doi:10.5194/bg-10-6225-2013, 2013.

Bouttes, N., Paillard, D., and Roche, D. M.: Impact of brine-induced stratification on the glacial carbon cycle, Clim. Past, 6, 575-589, doi:10.5194/cp-6-575-2010, 2010.

Brovkin, V., Ganopolski, A., and Svirezhev, Y.: A continuous climate-vegetation classification for use in climate-biosphere studies, Ecol. Model., 101, 251-261, 1997.

Brovkin, V., Bendtsen, J., Claussen, M., Ganopolski, A., Kubatzki, C., Petoukhov, V., and Andreev, A.: Carbon cycle, vegetation, and climate dynamics in the Holocene: Experiments with the CLIMBER-2 model, Global Biogeochem. Cy., 16, 1139, doi:10.1029/2001GB001662, 2002a.

Brovkin, V., Hofmann, M., Bendtsen, J., and Ganopolski, A.: Ocean biology could control atmospheric $\delta^{13} \mathrm{C}$ during glacialinterglacial cycle, Geochem. Geophy. Geosyst., 3, 1027, doi:10.1029/2001GC000270, 2002b.

Brovkin, V., Ganopolski, A., Archer, D., and Rahmstorf, S.: Lowering of glacial atmospheric $\mathrm{CO}_{2}$ in response to changes in oceanic circulation and marine biogeochemistry, Paleoceanography, 22, PA4202, doi:10.1029/2006PA001380, 2007.

Campin, J. M. and Goosse, H.: A parameterization of density driven downsloping flow for coarse resolution model in z-coordinate, Tellus, 51, 412-430, 1999.

Ciais, P., Sabine, C., Bala, G., Bopp, L., Brovkin, V., Canadell, J., Chhabra, A., DeFries, R., Galloway, J., Heimann, M., Jones, C., Quéré, C. L., Myneni, R., Piao, S., and Thornton, P.: Carbon and Other Biogeochemical Cycles, in: Climate Change 2013: The Physical Science Basis. Contribution of Working Group I to the Fifth Assessment Report of the Intergovernmental Panel on Climate Change, edited by: Stocker, T. F., Qin, D., Plattner, G.-K., Tignor, M., Allen, S., Boschung, J., Nauels, A., Xia, Y., Bex, V., and Midgley, P., Cambridge University Press, Cambridge, United Kingdom and New York, NY, USA, 2013.
Cox, P. M., Betts, R. A., Jones, C. D., Spall, S. A., and Totterdell, I. J.: Acceleration of global warming due to carbon-cycle feedbacks in a coupled climate model, Nature, 408, 184-187, doi:10.1038/35041539, 2000.

Craig, H.: Isotopic standards for carbon and oxygen and correction factors for mass spectrometric analysis of carbon dioxide, Geochim. Cosmochim. Ac., 12, 133-149, 1957.

Crowley, T.: Ice Age Terrestrial Carbon Changes Revisited, Global Biogeochem. Cy., 9, 377-389, 1995.

d'Orgeville, M., Sijp, W. P., England, M. H., and Meissner, K. J.: On the control of glacial-interglacial atmospheric $\mathrm{CO}_{2}$ variations by the Southern Hemisphere westerlies, Geophys. Res. Lett., 37, L21703, doi:10.1029/2010GL045261, 2010.

Duplessy, J.-C., Shackleton, N., Fairbanks, R., Labeyrie, L., Oppo, D., and Kallel, N.: Deep water source variations during the last climatic cycle and their impact on the global deepwater circulation, Paleoceanography, 3, 343-360, 1988.

Elsig, J., Schmitt, J., Leuenberger, D., Schneider, R., Eyer, M., Leuenberger, M., Joos, F., Fischer, H., and Stocker, T. F.: Stable isotope constraints on Holocene carbon cycle changes from an Antarctic ice core, Nature, 461, 507-510, doi:10.1038/nature08393, 2009.

EPICA community members: Eight glacial cycles from an Antarctic ice core, Nature, 429, 623-628, 2004.

Fichefet, T. and Morales Maqueda, M. A.: Sensitivity of a global sea ice model to the treatment of ice thermodynamics and dynamics, J. Geophys. Res., 102, 12609-12646, 1997.

Fichefet, T. and Morales Maqueda, M. A.: Modelling the influence of snow accumulation and snow-ice formation on the seasonal cycle of the Antarctic sea-ice cover, Clim. Dynam., 15, 251-268, 1999.

Franke, J., Paul, A., and Schulz, M.: Modeling variations of marine reservoir ages during the last 45000 years, Clim. Past, 4, 125136, doi:10.5194/cp-4-125-2008, 2008.

Friedlingstein, P., Bopp, L., Ciais, P., Dufresne, J.-L., Fairhead, L., LeTreut, H., Monfray, P., and Orr, J.: Positive feedback of the carbon cycle on future climate change, Geophys. Res. Lett., 28, 1543-1546, doi:10.1029/2000GL012015, 2001.

Friedlingstein, P., Cox, P., Betts, R., Bopp, L., von Bloh, W., Brovkin, V., Cadule, P., Doney, S., Eby, M., Fung, I., Bala, G., John, J., Jones, C., Joos, F., Kato, T., Kawamiya, M., Knorr, W., Lindsay, K., Matthews, H. D., Raddatz, T., Rayner, P., Reick, C., Roeckner, E., Schnitzler, K.-G., Schnur, R., Strassmann, K., Weaver, A. J., Yoshikawa, C., and Zeng, N.: Climate - Carbon Cycle Feedback Analysis: Results from the C4MIP Model Intercomparison, J. Climate, 19, 3337-3353, doi:10.1175/JCLI3800.1, 2006.

Garcia, H. E., Locarnini, R. A., Boyer, T. P., Antonov, J. I., Baranova, O. K., Zweng, M. M., and Johnson, D. R.: World Ocean Atlas 2009, Volume 3: Dissolved Oxygen, Apparent Oxygen Utilization, and Oxygen Saturation, edited by: Levitus, S., NOAA Atlas NESDIS 70, US Government Printing Office, Washington, D.C., 344 pp., 2010 a.

Garcia, H. E., Locarnini, R. A., Boyer, T. P., Antonov, J. I., Zweng, M. M., Baranova, O. K., and Johnson, D. R.: World Ocean Atlas 2009, Volume 4: Nutrients (phosphate, nitrate, silicate), edited by: Levitus, S., NOAA Atlas NESDIS 71, US Government Printing Office, Washington, D.C., 398 pp., 2010b. 
Goosse, H. and Fichefet, T.: Importance of ice-ocean interactions for the global ocean circulation: A model study, J. Geophys. Res., 104, 23337-23355, doi:10.1029/1999JC900215, 1999.

Goosse, H., Brovkin, V., Fichefet, T., Haarsma, R., Huybrechts, P., Jongma, J., Mouchet, A., Selten, F., Barriat, P.-Y., Campin, J.M., Deleersnijder, E., Driesschaert, E., Goelzer, H., Janssens, I., Loutre, M.-F., Morales Maqueda, M. A., Opsteegh, T., Mathieu, P.-P., Munhoven, G., Pettersson, E. J., Renssen, H., Roche, D. M., Schaeffer, M., Tartinville, B., Timmermann, A., and Weber, S. L.: Description of the Earth system model of intermediate complexity LOVECLIM version 1.2, Geosci. Model Dev., 3, 603-633, doi:10.5194/gmd-3-603-2010, 2010.

Kanzow, T., Cunningham, S. A., Johns, W. E., Hirschi, J. J.M., Marotzke, J., Baringer, M. O., Meinen, C. S., Chidichimo, M. P., Atkinson, C., Beal, L. M., Bryden, H. L., and Collins, J.: Seasonal Variability of the Atlantic Meridional Overturning Circulation at $26.5^{\circ} \mathrm{N}$, J. Climate, 23, 5678-5698, doi:10.1175/2010JCLI3389.1, 2010.

Key, R., Kozyr, A., Sabine, C., Lee, K., Wanninkhof, R., Bullister, J., Feely, R., Millero, F., Mordy, C., and Peng, T.-H.: A global ocean carbon climatology: Results from GLODAP, Global Biogeochem. Cy., 18, GB4031, 2004.

Kitover, D. C., van Balen, R. T., Roche, D. M., Vandenberghe, J., and Renssen, H.: New Estimates of Permafrost Evolution during the Last $21 \mathrm{k}$ Years in Eurasia using Numerical Modelling, Permafrost Periglac., 24, 286-303, doi:10.1002/ppp.1787, 2013.

Kwon, E. Y., Primeau, F., and Sarmiento, J. L.: The impact of remineralization depth on the air-sea carbon balance, Nat. Geosci., 2, 630-635, doi:10.1038/ngeo612, 2009.

Locarnini, R. A., Mishonov, A. V., Antonov, J. I., Boyer, T. P., Garcia, H. E., Baranova, O. K., Zweng, M. M., and Johnson, D. R.: World Ocean Atlas 2009, Volume 1: Temperature, edited by: Levitus, S., NOAA Atlas NESDIS 68, US Government Printing Office, Washington, D.C., 184 pp., 2010.

Lourantou, A., Lavric, J. V., Köhler, P., Barnola, J.-M., Paillard, D., Michel, E., Raynaud, D., and Chappellaz, J.: Constraint of the $\mathrm{CO}_{2}$ rise by new atmospheric carbon isotopic measurements during the last deglaciation, Global Biogeochem. Cy., 24, GB2015, doi:10.1029/2009GB003545, 2010.

Mariotti, V., Paillard, D., Roche, D. M., Bouttes, N., and Bopp, L.: Simulated Last Glacial Maximum $\Delta{ }^{14} \mathrm{C}_{\text {atm }}$ and the deep glacial ocean carbon reservoir, Radiocarbon, 55, 1595-1602, 2013.

Masarik, J. and Beer, J.: An updated simulation of particle fluxes and cosmogenic nuclide production in the Earth's atmosphere, J. Geophys. Res.-Atmos., 114, D11103, doi:10.1029/2008JD010557, 2009.

Matsumoto, K., Sarmiento, J. L., Key, R. M., Aumont, O., Bullister, J. L., Caldeira, K., Campin, J.-M., Doney, S. C., Drange, H., Dutay, J.-C., Follows, M., Gao, Y., Gnanadesikan, A., Gruber, N., Ishida, A., Joos, F., Lindsay, K., Maier-Reimer, E., Marshall, J. C., Matear, R. J., Monfray, P., Mouchet, A., Najjar, R., Plattner, G.-K., Schlitzer, R., Slater, R., Swathi, P. S., Totterdell, I. J., Weirig, M.-F., Yamanaka, Y., Yool, A., and Orr, J. C.: Evaluation of ocean carbon cycle models with data-based metrics, Geophys. Res. Lett., 31, L07303, doi:10.1029/2003GL018970, 2004.

Menviel, L., Joos, F., and Ritz, S.: Simulating atmospheric $\mathrm{CO}_{2}$, ${ }^{13} \mathrm{C}$ and the marine carbon cycle during the Last GlacialInterglacial cycle: possible role for a deepening of the mean rem- ineralization depth and an increase in the oceanic nutrient inventory, Quaternary Sci. Rev., 56, 46-68, 2012.

Mielke, C., Frajka-Williams, E., and Baehr, J.: Observed and simulated variability of the AMOC at $26^{\circ} \mathrm{N}$ and $41^{\circ} \mathrm{N}$, Geophys. Res. Lett., 40, 1159-1164, doi:10.1002/grl.50233, 2013.

Millero, F. J.: Thermodynamics of the carbon dioxide system in the oceans, Geochim. Cosmochim. Ac., 59, 661-677, doi:10.1016/0016-7037(94)00354-O, 1995.

Opsteegh, J., Haarsma, R., Selten, F., and Kattenberg, A.: ECBILT: A dynamic alternative to mixed boundary conditions in ocean models, Tellus, 50, 348-367, 1998.

Orr, J. C., Fabry, V. J., Aumont, O., Bopp, L., Doney, S. C., Feely, R. A., Gnanadesikan, A., Gruber, N., Ishida, A., Joos, F., Key, R. M., Lindsay, K., Maier-Reimer, E., Matear, R., Monfray, P., Mouchet, A., Najjar, R. G., Plattner, G.-K., Rodgers, K. B., Sabine, C. L., Sarmiento, J. L., Schlitzer, R., Slater, R. D., Totterdell, I. J., Weirig, M.-F., Yamanaka, Y., and Yool, A.: Anthropogenic ocean acidification over the twenty-first century and its impact on calcifying organisms, Nature, 437, 681-686, doi:10.1038/nature04095, 2005.

Prentice, I. C., Farquhar, G. D., Fasham, M. J. R., Goulden, M. L., Heimann, M., Jaramillo, V. J., Kheshgi, H. S., Quéré, C. L., Scholes, R. J., and Wallace, D. W. R.: The carbon cycle and atmospheric carbon dioxide, in: Climate Change 2001: The Scientific Basis. Contribution of Working Group I to the Third Assessment Report of the Intergovernmental Panel on Climate Change, edited by: Houghton, J. T., Ding, Y., Griggs, D. J., Noquer, M., van der Linden, P. J., Dai, X., Maskell, K., and Johnson, C. A., 183-237, Cambridge University Press, Cambridge, United Kingdom and New York, NY, USA, 2013.

Reimer, P. J., Baillie, M. G. L., Bard, E., Bayliss, A., Beck, J. W., Blackwell, P. G., Ramsey, C. B., Buck, C. E., Burr, G. S., Edwards, R. L., Friedrich, M., Grootes, P. M., Guilderson, T. P., Hajdas, I., Heaton, T. J., Hogg, A. G., Hughen, K. A., Kaiser, K. F., Kromer, B., McCormac, F. G., Manning, S. W., Reimer, R. W., Richards, D. A., Southon, J. R., Talamo, S., Turney, C. S. M., van der Plicht, J., and Weyhenmeyer, C. E.: INTCAL09 and MARINE09 radiocarbon age calibration curves, 0-50,000 years CAL BP, Radiocarbon, 51, 1111-1150, 2009.

Reimer, P. J., Bard, E., Bayliss, A., Beck, J. W., Blackwell, P. G., Ramsey, C. B., Buck, C. E., Cheng, H., Edwards, R. L., Friedrich, M., Grootes, P. M., Guilderson, T. P., Haflidason, H., Hajdas, I., Hatté, C., Heaton, T. J., Hoffmann, D., Hogg, A. G., Hughen, K. A., Kaiser, K. F., Kromer, B., Manning, S. W., Niu, M., Reimer, R. W., Richards, D. A., Scott, E. M., Southon, J. R., Staff, R. A., Turney, C. S. M., and van der Plicht, J.: INTCAL13 and MARINE13 radiocarbon age calibration curves, 0-50,000 years CAL BP, Radiocarbon, 55, 1869-1887, 2013.

Roche, D. M.: $\delta^{18} \mathrm{O}$ water isotope in the $i$ LOVECLIM model (version 1.0) - Part 1: Implementation and verification, Geosci. Model Dev., 6, 1481-1491, doi:10.5194/gmd-6-1481-2013, 2013.

Roche, D. M., Dokken, T. M., Goosse, H., Renssen, H., and Weber, S. L.: Climate of the Last Glacial Maximum: sensitivity studies and model-data comparison with the LOVECLIM coupled model, Clim. Past, 3, 205-224, doi:10.5194/cp-3-205-2007, 2007.

Roche, D. M., Dumas, C., Bügelmayer, M., Charbit, S., and Ritz, C.: Adding a dynamical cryosphere to iLOVECLIM (version 1.0): 
coupling with the GRISLI ice-sheet model, Geosci. Model Dev., 7, 1377-1394, doi:10.5194/gmd-7-1377-2014, 2014.

Schmitt, J., Schneider, R., Elsig, J., Leuenberger, D., Lourantou, A., Chappellaz, J., Köhler, P., Joos, F., Stocker, T. F., Leuenberger, M., and Fischer, H.: Carbon Isotope Constraints on the Deglacial $\mathrm{CO}_{2}$ Rise from Ice Cores, Science, 336, 711-714, doi:10.1126/science.1217161, 2012.

Schmittner, A., Gruber, N., Mix, A. C., Key, R. M., Tagliabue, A., and Westberry, T. K.: Biology and air-sea gas exchange controls on the distribution of carbon isotope ratios $\left(\delta^{13} \mathrm{C}\right)$ in the ocean, Biogeosciences, 10, 5793-5816, doi:10.5194/bg-10-5793-2013, 2013.

Schneider, B., Bopp, L., and Gehlen, M.: Assessing the sensitivity of modeled air-sea $\mathrm{CO}_{2}$ exchange to the remineralization depth of particulate organic and inorganic carbon, Global Biogeochem. Cy., 22, GB3021, doi:10.1029/2007GB003100, 2008.

Send, U., Lankhorst, M., and Kanzow, T.: Observation of decadal change in the Atlantic meridional overturning circulation using 10 years of continuous transport data, Geophys. Res. Lett., 38, L24606, doi:10.1029/2011GL049801, 2011.

Six, K. D. and Maier-Reimer, E.: Effects of plankton dynamics on seasonal carbon fluxes in an ocean general circulation model, Global Biogeochem. Cy., 10, 559-583, 1996.

Srokosz, M., Baringer, M., Bryden, H., Cunnigham, S., Delworth, T., Lozier, S., Marotzke, J., and Sutton, R.: Past, Present, and future changes in the Atlantic Meridional Overturning Circulation, B. Am. Meteorol. Soc., 93, 1663-1676, 2012.
Stuiver, M. and Polach, H.: Discussion: Reporting of ${ }^{14} \mathrm{C}$ data, Radiocarbon, 19, 335-363, 1977.

Takahashi, T., Sutherland, S. C., Wanninkhof, R., Sweeney, C., Feely, R. A., Chipman, D. W., Hales, B., Friederich, G., Chavez, F., Sabine, C., Watson, A., Bakker, D. C. E., Schuster, U., Metzl, N., Yoshikawa-Inoue, H., Ishii, M., Midorikawa, T., Nojiri, Y., Körtzinger, A., Steinhoff, T., Hoppema, M., Olafsson, J., Arnarson, T. S., Tilbrook, B., Johannessen, T., Olsen, A., Bellerby, R., Wong, C. S., Delille, B., Bates, N. R., and de Baar, H. J. W.: Climatological mean and decadal change in surface ocean $p \mathrm{CO}_{2}$, and net sea-air $\mathrm{CO}_{2}$ flux over the global oceans, Deep-Sea Res. Pt. II, 56, 554-577, 2009.

Tschumi, T., Joos, F., Gehlen, M., and Heinze, C.: Deep ocean ventilation, carbon isotopes, marine sedimentation and the deglacial $\mathrm{CO}_{2}$ rise, Clim. Past, 7, 771-800, doi:10.5194/cp-7-771-2011, 2011.

Tyndall, J.: On the Absorption and Radiation of Heat by Gases and Vapours, and on the Physical Connexion of Radiation, Absorption, and Conduction, Philos. T. Roy. Soc. London, 151, 1-36, 1861.

Weaver, A. J., Sedláček, J., Eby, M., Alexander, K., Crespin, E., Fichefet, T., Philippon-Berthier, G., Joos, F., Kawamiya, M., Matsumoto, K., Steinacher, M., Tachiiri, K., Tokos, K., Yoshimori, M., and Zickfeldi, K.: Stability of the Atlantic meridional overturning circulation: A model intercomparison, Geophys. Res. Lett., 39, L20709, doi:10.1029/2012GL053763, 2012. 